\title{
Entre o Leviatã e o Beemote: Soberania, Constituição e Excepcionalidade no Debate Político dos Séculos XVII e XVIII
}

Christian Edward Cyril Lynch

\section{INTRODUÇÃO}

É curioso que um autor como Thomas Hobbes, que, com tanta ênfase, sublinhava a necessidade de exprimir o pensamento de forma clara e direta, tenha batizado duas de suas principais obras com metáforas extraídas de personagens-monstros descritos na Bíblia: o Leviatã (Leviathan) e o Beemote (Behemoth). Espécie de dragão ou de serpente, o primeiro deles, reinando sobre os filhos do orgulho (os homens), designaria o poder soberano do Estado; poder pacificador que, graças à reverência incutida por seu poder e autoridade, evitava o conflito que levava à guerra civil. O triunfo desta última era simbolizado pelo segundo monstro, o Beemote, espécie de hipopótamo cujo significado é, todavia, menos evidente. Seja como for, alude à eventual divisão e à fraqueza do poder soberano que, incapaz de conter o orgulho humano, abriria as portas para as facções, a fragmentação social e a guerra civil (Ribeiro, 2001:13). No entanto, o que os comentadores da obra de Hobbes deixam em segundo plano é que aquela fragmentação do poder soberano, que desaguaria na morte do Estado, tinha uma forma constitucional. É para esse fato que quero chamar a atenção neste artigo.

Sempre presente no discurso das facções estaria a reivindicação de um modo distinto de distribuir o poder e que passaria por desconcentrá-lo em proveito de outros corpos representativos da comunidade, para

DADOS - Revista de Ciências Sociais, Rio de Janeiro, vol. 53, no 1, 2010, pp. 55 a 90. 
além do monarca, como a nobreza e o povo. A essa maneira de organizar o poder político, ao largo da concepção unitária e indivisível do conceito de soberania, as facções dariam o nome de constituição mista, ou governo misto. Porque levava à incerteza quanto ao problema da obediência última, desaguando no conflito político da guerra civil, $a$ constituição mista reivindicada pelo clero e pela nobreza contra a concentração de poder monárquica não passava, para Hobbes, de "pura anarquia" (2001:168). Em outras palavras, o governo misto era a roupagem institucional do Beemote.

As metáforas hobbesianas do Leviatã e do Beemote servem aqui de preâmbulo às problemáticas relações conceituais entre soberania e governo misto, ou constitucional, entre o político e o jurídico, e que remontam, em última análise, à questão matricial do uno e do múltiplo na filosofia. O objetivo deste artigo é, justamente, retraçar os caminhos teóricos percorridos pelo problema da excepcionalidade, no entrecruzamento do conceito de soberania com o de constituição mista, enquanto manifestação do poder soberano no interior de um governo constitucional. O conceito de soberania declarava a indivisibilidade e o absolutismo do poder, ao passo que o governo misto buscava dividi-lo e limitá-lo. Elevando a preservação da sociedade à condição de finalidade primeira do poder, a concentração do poder nas mesmas mãos seria imperiosa para unificar e conservar uma sociedade que, em face de suas tendências centrípetas, tenderia permanentemente à anarquia e à guerra civil. Ocorre que os caracteres de unidade, hierarquia e discricionariedade do poder soberano se acomodam mal ao conceito de constituição mista: como falar de unidade, de hierarquia e de discricionariedade num governo de cidadãos iguais e livres, em direitos e deveres, agindo sob o abrigo de leis comuns?

Já presente em autores como Maquiavel, Harrington e Locke, o debate se bifurcou no começo do século XVIII e teve diferentes seguimentos na Inglaterra e na França. Se, por um lado, as especificidades da política inglesa levaram-na a consagrar uma tradição de governo misto em que o elemento discricionário perdia relevância no conjunto do sistema político, por outro, a impopularidade do estamento nobiliárquico e a centralidade do conceito de soberania desacreditaram, na França, fórmulas que contemporizassem com o caráter discricionário do poder. Essa bifurcação contribuiu para a formação de dois padrões distintos de governo constitucional: o anglo-saxão, marcado pelo controle 
jurisdicional da constitucionalidade das leis, e o franco-continental, caracterizado pelo poder moderador encarnado no chefe do Estado.

Na primeira seção deste artigo, faço um apanhado da questão atinente aos temas da constituição mista, da soberania e da excepcionalidade até meados do século XVII, servindo de prólogo ao objeto propriamente dito desta investigação, que ocupa, por seu turno, as duas seções seguintes: o debate político atinente àqueles conceitos na Inglaterra e na França, durante o Século das Luzes, isto é, a centúria que precedeu a Revolução Francesa (1688-1788). Nas duas seções posteriores ao prólogo, sigo a linha do contextualismo linguístico de Quentin Skinner e John A. Pocock. Tais autores se qualificavam no interior da chamada viragem linguística, que politicamente preconiza o abandono da abordagem metafísica do discurso em benefício de seu exame enquanto convenção dialógica fundada numa radicalidade pragmática e contextual. Conforme sustenta Richard Rorty (1984), o estudioso deveria abandonar a perspectiva idealista que se centra nos chamados "grandes autores", fazendo uma análise exclusivamente interna e abstrata de suas obras, para examinar seus escritos ou discursos como atos de fala politicamente motivados, em seu contexto originário polêmico, que envolvia autores "menores" na condição de seus aliados ou adversários - numa palavra, a partir de seu contexto político. Entre as várias noções centrais da Escola de Cambridge para a configuração do campo semântico da cultura política, interessa-me sobretudo a de discurso, linguagem ou ideologia em suas três acepções: pensamento considerado retórica ou discurso em ação; pensamento determinado e limitado pelas formas de discurso disponíveis para sua expressão e, às vezes, em tensão com elas; e uma visão de mundo determinada por vários fatores, sem que haja uma única teoria preconcebida acerca deles (Pocock, 1985:216). Por fim, gostaria de render homenagem aos cultos pareceristas que generosamente criticaram a primeira versão deste artigo e fizeram sugestões que busquei incorporar.

\section{PREMISSAS TEÓRICAS DO DEBATE SETECENTISTA: SÍNTESE DOS TEMAS DE CONSTITUIÇÃO MISTA, SOBERANIA E EXCEPCIONALIDADE ATÉ AS VÉSPERAS DAS LUZES}

Nesta seção, conforme referido, limito-me a fazer um apanhado do estado da questão sobre constituição mista, soberania e excepcionalidade até meados do século XVII. Trata-se apenas de mostrar, em linhas gerais, a herança que os pensadores do Iluminismo na França e na 


\section{Christian Edward Cyril Lynch}

Inglaterra tomariam como premissas para o debate que estabeleceriam em seu próprio tempo, e que é o objeto sobre o qual se debruça propriamente este artigo.

O mais longevo traço da reflexão política, entendida como ramo prático da filosofia, tem sido especular sobre o modo mais justo de organização das comunidades humanas. Outro não foi o objetivo da teoria clássica das constituições, ou formas de governo, elaborada desde a Antiguidade clássica e que teve enorme impacto na enunciação dos parâmetros centrais do pensamento político até pelo menos o século XVIII. Entre as diversas contribuições do pensamento grego para o constitucionalismo, como as de Heródoto e Platão, foi aquela deixada por Aristóteles a que mais força exerceu no período posterior. Pondo de lado a tipologia constitucional platônica, que julgava demasiado marcada pela rejeição da empiria, e valendo-se do critério puramente quantitativo prevalecente em seu tempo para a classificação das constituições puras - monarquia, aristocracia e democracia -, Aristóteles acrescentou-lhe outro, de caráter qualitativo, relativo aos valores públicos ou privados que orientariam os governantes no exercício do poder. Assim, por exemplo, quando o governo fosse exercido por um único e se orientasse pela aspiração de atender ao bem comum, ele poderia ser qualificado adequadamente como monárquico; caso dele participassem apenas as melhores famílias, poderia ser denominado aristocrático. Entretanto, quando o móvel do governo fosse não distribuir justiça para todos, mas tão somente favorecer os governantes, outro era seu nome: não monárquico, mas tirânico; não aristocrático, mas oligárquico. Haveria, então, não três, mas seis constituições, três boas, porque guiadas pelos valores cívicos - monarquia, aristocracia e politeia -, e três más, porque guiadas pelo particularismo - tirania, oligarquia e democracia.

Quanto ao governo misto, Aristóteles (1997) concordava com a assertiva platônica de que a constituição de Esparta se aproximava da forma mista, que seria efetivamente a melhor (ibid.:91 e 49). No entanto, ele discordava do modo como o mestre encaminhara o problema, sugerindo que a combinação adequada era entre oligarquia e democracia. Como a primeira refletia os interesses dos ricos, e a segunda, dos pobres, a combinação - politeia - remediaria a luta dos despossuídos contra os proprietários, que era a mais importante causa de instabilidade constitucional (Wolff, 1999:112). Isso seria ainda mais verdadeiro caso houvesse, entre as duas classes, uma intermediária, destituída de 
qualquer interesse particular na mudança do regime, fosse para oligárquico, fosse para democrático (Morrall, 2000:68).

Em Roma, a formulação que maior fortuna teria acerca das tipologias constitucionais e do lugar da forma mista foi elaborada pelo general e historiador romano Políbio - especialmente a partir de sua primeira tradução do original grego, escrito em torno de 1520 -, com base na tipologia constitucional de Aristóteles. Se os dois critérios estabelecidos pelo estagirita - o quantitativo (quantos governam) e o qualitativo (como governam) - compunham uma dimensão estática da teoria das formas de governo, Políbio acrescentava uma segunda dimensão, de natureza dinâmica, relativa à interação das seis formas aristotélicas no tempo, que pressupunha a imutabilidade da natureza humana, sua tendência inevitável à corrupção e o caráter cíclico da história. Fadadas inevitavelmente a desaparecerem, como tudo no mundo, as seis formas de governo seriam essencialmente instáveis, sucedendo-se alternativamente na experiência histórica. Ou seja, a experiência demonstrava a instabilidade das formas de governo, que oscilavam constantemente entre boas e más. Seria possível evitar sua corrupção ou ao menos reduzir a velocidade de sua degeneração? A partir das ponderações aristotélicas sobre o governo misto, mas considerando a inexorabilidade dos efeitos corrosivos do tempo sobre as virtudes cívicas, Políbio mesclou não duas, mas as três formas puras de governo, conforme o critério quantitativo (monarquia, aristocracia e democracia), purgando-as dos aspectos que poderiam antagonizá-las reciprocamente. Era, segundo Políbio, a constituição adotada por Roma ao proclamar-se república e que ele alçava à condição de causa eficiente de sua estabilidade e glória. O elemento monárquico, representado por dois cônsules, sujeitava-se ao controle aristocrático do Senado, ao passo que este ficava sob a vigilância dos comícios populares. Por meio de mecanismos de freios e contrapesos, seria possível balancear os três elementos constitucionais, daí resultando um equilíbrio que evitava as mudanças bruscas e favorecia o gradualismo (Políbio, 1996:348).

Com a autonomia do ético-político em face da religião, durante dez séculos desapareceu a reflexão constitucional produzida na Antiguidade, que foi substituída por metáforas organicistas da Idade Média: a teologia política medieval compreendia a comunidade cristã como um corpo encabeçado pelo rei, cujos braços eram a nobreza; as pernas, o povo; e o coração, o clero (Kantorowicz, 1998:125). Somente depois da redescoberta da parte política da obra de Aristóteles, no século XIII, os 
autores do medievo tardio puderam acessar a reflexão constitucional clássica para repensar suas próprias considerações políticas. O mais célebre desses autores foi São Tomás de Aquino, que fez de sua reflexão uma adaptação da filosofia aristotélica à luz da revelação cristã, tendo ressuscitado, igualmente, o ideal do governo misto como o mais conforme ao bem comum - bem que resulta, todavia, não apenas da razão prática, como pretendia Aristóteles, mas da realização do reino de Deus a que era possível alcançar por meio da graça (Aquino, 1995:95 e 119). O objetivo de São Tomás, porém, é menos o equilíbrio social, já presente na ordem das coisas, do que refletir, em torno do centro ordenador do príncipe, a representação dos magistrados, oficiais, bispos e barões que deveriam prestar-lhe auxílio e conselho e assim moderá-lo. Em sua estrutura interna, a constituição mista repousava sobre o consenso entre o monarca e os estamentos quanto às decisões políticas fundamentais; na estrutura externa, baseava-se na concepção de uma república cristã em que a Igreja prevalecia sobre as autoridades reinóis (Beaud, 1994:43). Em outros autores, especialmente os ingleses, a tradicional explicação organicista do governo se revestia das roupagens do governo misto. Assim, embora reconhecesse o monarca como a cabeça do corpo social, Fortescue sublinhava, em virtude da interdependência das diversas partes do corpo, a necessidade de o monarca viver em harmonia com a nobreza, elemento aristocrático, e o povo, elemento democrático (Voegelin, 1982:42).

No entanto, a escalada de guerras e de epidemias que dizimaram a Europa ocidental e central durante a baixa Idade Média passou a exigir desses reis a satisfação de carências gerais extraordinárias, cujos recursos só podiam ser obtidos pela derrogação das normas de convivência vassálica. Os monarcas recorreram então ao arsenal de ideias desenvolvidas pelo imperador e pelo Papa, desde a Questão das Investiduras, para superar os limites impostos pela concepção cristológica do poder, lançando mão do conceito de soberania (Skinner, 1996:38). Foram os juristas os principais artífices intelectuais da operação, que estendia aos monarcas a categoria romana de princeps para estabelecer sua supremacia no âmbito de seus reinos (Bignotto, 2001:38). A nova doutrina da excepcionalidade do poder continha, todavia, duas novidades: a secularidade do ofício e a categoria de necessidade. Por um lado, "o bom rei é antes aquele que conhece os meios de manter a coesão social do que os de submeter os cristãos à lei divina" (Saint-Bonnet, 2001:118; tradução minha); por outro, estava ele autorizado a emergencialmente abandonar as normas costumeiras para exercer o poder de 
maneira discricionária quando ele fosse necessário à salvação do reino. Os juristas reinóis resgatavam assim a máxima de Graciano: Necessitas non habet legem (Bercovici, 2008:56). Fixaram-se então os três caracteres políticos tradicionais do estado de exceção: a excepcionalidade da ocasião, a necessidade de uma ação pronta e a finalidade de salvação do Estado. A doutrina do estado de exceção facultou juridicamente aos reis superar as regras feudais de convivência vassálica para, unilateralmente, aumentar os tributos, requisitar a força armada, legislar, expropriar e assim, paulatinamente, estender sua autoridade pelo território do reino.

Na medida em que a escalada de guerras dos séculos XV e XVI acabou por rotinizar o estado de exceção, a tendência dos monarcas foi considerar aquele acréscimo de seu poder como parte da própria prerrogativa em prejuízo dos demais corpos da constituição mista, como a Igreja, a nobreza, as cidades etc. Foram duas as doutrinas desenvolvidas no século XVI pelos juristas da Coroa para justificar a consolidação daquele poder nas mãos dos príncipes: a razão de Estado e a soberania monárquica.

A razão de Estado destacava que a segurança do Estado impunha aos governantes a eventual violação das normas jurídicas, morais, políticas e econômicas ordinariamente vigentes. Em face do constante perigo de decomposição da ordem, o príncipe precisava estar armado para conjurá-lo, recorrendo, se preciso, à violência e ao segredo (Pistone, 1998:1066; Zarka, 2003:612; Meinecke, 1973:11). Já a teoria da soberania era mais radical: da oposição entre a premência de ordem, condição da política institucional, e a realidade conflituosa decorrente do dissenso moral resultava a superioridade do valor da vida sobre o da liberdade. Daí a razão por que toda a população do reino deveria se subordinar a uma única e indivisível autoridade, tornada absoluta, perpétua e insubmissa a qualquer lei positiva. Olegislador era soberano e, por isso, não poderia estar localizado na sociedade, lugar da ambição e do conflito, mas fora, onde fosse visto por todos como um terceiro imparcial, isto é, o representante existencial da comunidade (Voegelin, 1982:45). Embora possuíssem diferenças de gradação, as afinidades entre as duas doutrinas eram mais fortes, pelo que acabaram por se entrelaçar. Assim, por exemplo, Amelot de la Houssaye (1634-1706) declarava que "a razão de Estado era um direito inseparável da soberania, em virtude do qual o príncipe não tinha de prestar contas de suas vontades" (apud Morel, 2003:5; tradução minha). Na mesma linha, o 


\section{Christian Edward Cyril Lynch}

principal artífice do absolutismo francês, o Duque de Richelieu (1585-1642), primeiro-ministro de Luís XIII, não era doutrinário da soberania monárquica, mas da razão de Estado: "O que é contingente, no seu começo, torna-se algumas vezes necessário em seguida [...]. É preciso, em certas ocasiões, para o bem do Estado, uma virtude máscula que passa algumas vezes por cima das regras da prudência ordinária" (Richelieu, 1959:26 e 39).

Foi assim que, independentemente de suas justificativas naturalistas, contratuais ou patriarcais, os teóricos da soberania absoluta repeliram como subversiva a milenar doutrina da constituição mista. A indivisibilidade, a inalienabilidade e a incomunicabilidade da soberania eram incompatíveis com a noção de exercício partilhado do poder, que importava no enfraquecimento da disciplina social. Assim, se para Jean Bodin (1530-1596) o "regime misto" era um disparate, para Thomas Hobbes (1588-1679) a duração da constituição mista dependia do frágil acordo entre os elementos que o compunham; quando ele se desfizesse, "o Estado retorna[ria] à guerra civil e ao direito do gládio privado", o que, para ele, era "muito pior do que qualquer tipo de sujeição" (Bodin, 1993:71; tradução minha; Hobbes, 1998:122). O mais enfático na condenação da velha forma política polibiana, porém, era o famoso Sir Robert Filmer (1588-1653), autor de opúsculos cujos títulos eram autoexplicativos - como A Anarquia de uma Monarquia Mista ou Limitada:

Políticos, filósofos, sacerdotes e historiógrafos sábios têm vivamente recomendado a monarquia como superior a todas as outras formas de governo. Não é para agradar ao príncipe que eles sustentam essa opinião, mas para a felicidade e a segurança dos súditos. Caso contrário, se eles limitassem e restringissem a soberania absoluta do monarca [...], a soberania não teria alicerces sólidos, e eles conseguiriam assim uma confusão popular ou uma miserável anarquia, que é a praga de todos os estados e repúblicas (Filmer, 1991:181; tradução minha).

Isso não quer dizer que as doutrinas da razão de Estado e da soberania preconizassem um poder monárquico ilimitado, muito menos que ele o tenha sido verdadeiramente na realidade histórica. Os teóricos da soberania, como Bodin e Hobbes, viam no poder soberano o garante da vida, da segurança e da propriedade dos súditos, ao passo que os doutrinários da razão de Estado, como Pierre Charron e Gabriel Naudé, entendiam que "o golpe de Estado" apenas em ocasiões excepcionais se justificava (Saint-Bonnet, 2001:190 e 212; Senellart, 1989:55; 
Bercovici, 2008:82). A própria reiteração de ambas as doutrinas em público é evidência de que a contestação do absolutismo jamais cessou de todo ao longo dos três séculos do Antigo Regime, promovida por setores sociais aristocráticos ou burgueses que a ele antepunham a prevalência das antigas concepções constitucionais mistas - no caso da França, as leis fundamentais do reino, ou a antiga Constituição, no caso da Inglaterra.

O humanismo ou republicanismo cívico, clássico ou neorromano, e o constitucionalismo antiquário foram as linguagens políticas com que os críticos da monarquia absoluta contribuíram para preservar e atualizar o antigo conceito de governo misto, pleiteando a limitação do poder por meio de leis que submetessem igualmente governados e governantes (Maddox, 1989:59). Para além do âmbito da teologia política, a moldura político-constitucional platônica, aristotélica e depois polibiana também deu sazonados frutos nos autores renascentistas que, escrevendo nas cidades italianas encravadas entre o Papa e o imperador germânico, pensavam como desenvolver uma vida cívica a partir da herança republicana da Antiguidade clássica. Nesse contexto, avultava a temática do governo misto, introduzida em Florença por Leonardo Bruni (1369-1444) e depois reaproveitada, com os matizes correspondentes a cada momento político, por outros autores, como Francesco Guicciardini (1483-1540) e Nicolau Maquiavel (1469-1527), em parte graças à melíflua visão de Veneza como modelo constitucional misto de equilíbrio e estabilidade (Pocock, 1997; Skinner, 1999; Bignotto, 2001:199; 2006:106).

Contrabandeada essa literatura para a Inglaterra seiscentista, nela vamos encontrar, em meados do século, James Harrington (1611-1677) e Algernon Sidney (1623-1683) se debruçando sobre os meios de distribuir justiça numa cidade em que fossem todos governados por consentimento e as liberdades estivessem protegidas por um governo misto contra a corrupção dos costumes (Pocock, 2003:89). Por outro lado, Sir Edward Coke (1552-1634) e Matthew Hale (1609-1676) advogavam o primado da antiga constituição feudal, que impunha ao monarca governar juntamente com a nobreza e o povo e respeitar os direitos concedidos a seus súditos. No entanto, a hostilidade desses autores à discricionariedade do poder não os impedia de reconhecer, por vezes, a utilidade de tolerá-lo em certos e determinados casos. Poucos deles acreditavam na possibilidade de banir para sempre o poder absoluto especialmente quando a comunidade política estivesse ameaçada por 
um grande e iminente perigo. Nesse caso, porém, como seria possível conciliar a existência potencial de um poder absoluto na moldura de um governo limitado? Não era expor em demasia as instituições que garantiam a liberdade, arriscando-as a morrerem por dose excessiva do remédio que, ao contrário, deveria salvá-las?

Uma primeira resposta possível era aquela desenvolvida por Maquiavel em seus Comentários sobre a Primeira Década de Tito Lívio. A despeito de proclamar a excelência da república, identificada ao governo misto, na tarefa de assegurar a glória de seus cidadãos, Maquiavel (1994) reconhecia a necessidade de suspender a constituição e concentrar os poderes públicos nas mãos de um único magistrado, quando perigava a subsistência da república. Uma vez que a necessidade era um elemento externo de completa imprevisibilidade, ela exigia dos governantes habilidades que estavam para além de qualquer legalidade ou moralidade (Sennelart, 1989:37). O precedente invocado por Maquiavel era o da ditadura romana, a mais importante instituição da república na medida em que viabilizava as condições de sua sobrevida. Isso não queria dizer que o governante ficava livre para agir de modo arbitrário, ou seja, absolutamente desprovido de limitações. Se não houvesse uma regulamentação geral e impessoal da própria ditadura, preconizando as fórmulas e as hipóteses de instauração e de duração, ela poderia tornar-se tirânica. Eis por que as hipóteses de suspensão excepcional da legalidade deveriam ser previstas pela própria constituição, disciplinando o prazo e a forma de exercício da ditadura (Maquiavel, 1994:114). Era essa a única forma de escapar ao dilema de escolher, diante do perigo premente, entre duas alternativas igualmente ruins o legalismo suicida e a discricionariedade tirânica.

A segunda resposta possível ao problema da discricionariedade foi elaborada por John Locke (1632-1704). A leitura de Maquiavel convencera Locke da dificuldade de se estabelecer de antemão o alcance dos poderes excepcionais a serem atribuídos ao governo, por causa da imprevisibilidade decorrente da guerra, da rebelião ou da catástrofe (Fatovic, 2004:282). Nesses casos, coerentemente, o autor da Carta sobre a Tolerância entendia que o chefe do Estado deveria se julgar autorizado para agir conforme seu juízo de conveniência e oportunidade. Entre as competências arroladas como prerrogativa da Coroa, as mais importantes eram convocar, prorrogar e dissolver o Parlamento, e agraciar e comutar penas individuais. Estabelecidas as leis de funcionamento da comunidade pela confirmação da lei natural, só o Executivo poderia 
bem ajuizar da oportunidade de novas regras e, por conseguinte, da conveniência de se reunir ou dissolver o Parlamento. Além disso, entre a abstração e a generalidade do tipo normativo, de um lado, e a realidade imprevisível da ação humana, de outro, sempre haveria casos em que uma condenação seria injusta, apesar de legal, mal que só poderia ser sanado por um poder supralegal. Como Maquiavel, porém, Locke se apressava em esclarecer que o exercício da prerrogativa pelo governo não passava de um "encargo fiduciário que lhe é confiado para a segurança do povo, nos casos em que a incerteza e a inconstância dos negócios humanos não comportam regra fixa" (Locke, 1998:524). Cabia ao Parlamento velar para que, em tais hipóteses, a Coroa não exorbitasse os limites autorizados à ação discricionária. Caso o Poder Legislativo não coibisse o exercício arbitrário da prerrogativa pelo Executivo, o povo prejudicado poderia fazê-lo por meio da resistência ou da rebelião. Ao permitir a uma ordem constitucional lacunosa suprir suas próprias aporias conforme circunstâncias que ela não poderia prever, $\mathrm{o}$ poder de exceção constituía um meio discricionário de promover, em momentos extraordinários, o fim promovido pela lei em circunstâncias normais - o bem comum (Fatovic, 2004:279).

\section{ORIGENS DO PADRÃO ANGLO-SAXÃO DE GOVERNO CONSTITUCIONAL: A TEORIA DA CONSTITUIÇÃO EQUILIBRADA E A PRECEDÊNCIA DO DIREITO SOBRE O POLÍTICO}

As reflexões efetuadas no século XVII sobre o tema da discricionariedade regulada impactaram de forma diversa o delineamento dos padrões político-constitucionais que marcaram o advento do Estado moderno, o inglês e o francês, na centúria seguinte. No início do século XVIII, três linguagens concorriam na Inglaterra para explicar a origem e a prática do poder político legítimo: 1) direito divino; 2) contrato originário; e 3) antiga Constituição. A primeira era sustentada pelos tories jacobitas, que, temendo o democratismo da Revolução Gloriosa, negavam a legitimidade da dinastia Hannover e ratificavam a origem divina da soberania monárquica. No entanto, essa teoria perdeu força em torno de 1740, quando seus adeptos se convenceram da estabilidade do sistema adotado em 1689. O segundo discurso vigente correspondia àquele da teoria lockeana, que obteve a adesão de poucos radicais até a década de 1760 (Dickinson, 2002:8). Depois de atingidos seus objetivos mais imediatos, com a queda da dinastia Stuart e a ascensão do partido whig, as ideologias republicana e contratual passaram, porém, a ser perigosas para a própria classe política que as forjara, na medida 
em que a categoria de soberania do povo poderia ser apropriada pelos inimigos da véspera para justificar nova ruptura da ordem. Era por esse motivo que a oligarquia whig situacionista preferia explicar a Constituição inglesa à moda do constitucionalismo antiquário, ou seja, como um governo misto caracterizado como um sistema de freios e contrapesos - versão que granjeou, aliás, a adesão esmagadora da literatura política da primeira metade do século XVIII (Bailyn, 2003:250).

No entanto, provocada pelas mudanças ocorridas na estrutura social do país, a luta política inglesa da década de 1720 marcaria a decadência do republicanismo cívico e a transição do constitucionalismo antiquário para aquilo que viria a ser conhecido como liberalismo. Chefiada por Henry Saint-John, Visconde de Bolingbroke (1678-1751), a oposição tory recorria insistentemente ao arsenal ideológico do constitucionalismo antiquário e do republicanismo cívico para acusar o governo de corromper a antiga Constituição pelo comércio e pelas finanças. Os republicanos compreendiam a cidadania a partir da noção de virtude, que envolvia um devotamento ao bem comum de tal ordem que só um ego autônomo das paixões poderia realizar. Como ensinavam os antigos, a virtude estava relacionada à propriedade rural, à contemplação, à sabedoria, à probidade pessoal, à moderação, à austeridade. Por isso mesmo, ela estava ameaçada todo o tempo de ser corrompida pelo luxo, pela cidade, pelo comércio, pelos excessos, pelo desregramento. Numa luta em que a ambição e a vanglória dilaceravam a cidade, a existência de partidos era um sinal indelével da decadência dos costumes públicos. Promovidas pelo gabinete whig de Sir Robert Walpole (1676-1745), a manutenção de um Exército profissional, o clientelismo parlamentar e a expansão da dívida pública, que criava uma classe intermediária urbana de rentistas, contrariavam as premissas éticas do discurso republicano clássico, dando ensejo a um encarniçado debate sobre o lugar da virtude numa sociedade dominada pela indiferença cívica e pelo interesse econômico. A ascendência dos ministros da Coroa sobre o Parlamento, por meio do patronato, configurava um despotismo ministerial que corrompia a constituição mista ao alienar o rei dos negócios públicos e interferir na independência do Legislativo. A manutenção de um Exército profissional, por sua vez, era o prenúncio da tirania que haveria de, mais cedo ou mais tarde, abater os históricos direitos dos ingleses (Pocock, 1997:495).

Em “The Idea of a Patriot King", Bolingbroke [1738] concitava o príncipe herdeiro da Inglaterra a retomar as rédeas do Estado das mãos da 
oligarquia whig assim que coroado. Nascida no período gótico, bastião das liberdades públicas, a estabilidade da constituição mista da Inglaterra dependia da independência e do equilíbrio dos elementos que a compunham - o monárquico (coroa), o aristocrático (lordes) e o democrático (comuns). Era justamente esse equilíbrio que vinha sendo destruído pela corrupção promovida pela facção whig, chefiada por Walpole, que usurpava a liderança do rei e, subornando lordes e comuns para alinhá-los ao governo, hipertrofiava o elemento monárquico em detrimento dos demais. O único meio de salvar a Constituição contra a atividade nefasta e particularista das facções passava por restaurá-la, isto é, remontá-la aos princípios que haviam presidido à sua criação, na forma de um retorno às origens. Recolocar as coisas em seus devidos e originários lugares exigia, porém, a intervenção superveniente de uma força política suprema, de caráter excepcional, decidida a desalojar e a esmagar os partidos que dividiam o povo. Ora, apenas o exercício emergencial da prerrogativa régia, argumentava Bolingbroke, permitiria à Inglaterra restaurar a Constituição, desfazendo-se dos maus governos que a comprometiam e reparando os estragos provocados pela corrupção partidária. A primeira providência a ser tomada por um rei patriota era livrar-se dos ministros corrompidos e de suas facções, substituindo-os por verdadeiros estadistas comprometidos com o bem comum, modelos de sabedoria, austeridade e virtude, ou seja, alheios às paixões (Pocock, 1997:493). Bolingbroke pintava assim um governante ideal, cujo dever era manter-se acima dos partidos: em vez de fomentar as divisões no corpo social, o rei patriota deveria agir como um verdadeiro guardião da Constituição. A exemplo de uma família "cuja cabeça e todos os membros estão unidos pelo interesse comum e animados por um espírito comum" (Bolingbroke, 1738; tradução minha), a nação deveria poder contar sempre com seu rei para exercer o papel de centro de uma grande união nacional, cuja voz pudesse ser ouvida sempre pelo povo por sobre os clamores dos partidos.

A essa visão tradicional da Constituição, predominante no discurso republicano, jornalistas e intelectuais favoráveis a Walpole contrapuseram uma concepção alternativa, a partir de uma teorização da versão constitucional antiquária que, na defesa dos novos valores ligados ao comércio, ao crédito e à cidade, enfatizava a necessidade de se repensar o lugar das paixões e dos interesses nos tempos modernos. Sublinhando a distinção do mundo social entre esfera privada e esfera pública, autores como Bernard de Mandeville (1670-1733) e David 
Hume (1711-1776) postularam que, em vez de reprimidos em nome de valores puramente morais, as paixões e os interesses individuais deveriam ser pragmaticamente aproveitados no mundo social para civilizar os costumes e garantir as liberdades políticas. Desde que moderados por sua recíproca contraposição, os vícios privados serviam ao bem comum e libertavam o mundo do jugo da fortuna, favorecendo a regularidade e a previsibilidade da vida (Hirschman, 2001:25). Proclamava-se um mundo de história dinâmica, sem princípios nem virtù, no qual, embora os homens se orientassem pelos interesses e pelas paixões individuais, era o bem comum que prevalecia na esfera pública. A crença de que, na origem da vida social, havia uma verdade ou uma essência a que se poderia remontar, por meio de uma revolução/restauração, era substituída por uma concepção de história na qual o presente deixava de ser prisioneiro do passado e ganhava autonomia; cujo vetor, em vez de cíclico e subordinado à tradição, como pensara Políbio, era linear e aberto à novidade. Era o horizonte de expectativas do mundo político que gradualmente se emancipava do campo de experiência, ou seja, da tradição: embora devessem ser evitadas rupturas, preservando-se os costumes que coordenavam o mundo social, era absolutamente quimérico, por outro lado, acreditar na absoluta intangibilidade da ordem de coisas, que inevitavelmente variavam, ainda que de modo insensível e não premeditado. Sinônima de governo constitucional e representativo, a Constituição inglesa era descrita como um governo misto, cujos poderes eram separados por especialização e que se relacionavam por mecanismos de freios e contrapesos.

Esse conservadorismo prescritivo, verdadeira fórmula protoliberal, encontrou seu alicerce na filosofia política de Hume, para quem nossas ideias acerca do mundo não seriam produzidas pela razão, mas pela experiência validada pela memória. Embora descomprometidas com a verdade científica, eram elas, porém, as responsáveis pela trama do tecido social, que convalidava regras de convivência vantajosas para todos. Se o reconhecimento da limitação cognitiva conduzia a uma postura de saudável resignação, que passava à revalorização do mundo cotidiano em prejuízo de lucubrações abstratas, o homem político não deveria arriscar instituições que, a despeito das disputas partidárias, garantiam de facto os direitos fundamentais, produzindo dirigentes de qualidade razoável e distribuindo a justiça num ambiente de paz e ordem (Hume, 1984:201 e 245). A simplicidade política, social e econômica do mundo romano ou gótico se encontrava num passado distante; os desafios do mundo presente, sobretudo de caráter econômico, pou- 
co tinham a ver com aqueles descritos pelo republicanismo, preocupado com glória e virtude. Assim, por exemplo, aquilo que parecia corrupção aos olhos da oposição republicana decorria, na verdade, de uma inelutável mudança socioeconômica e cultural, que impunha aos ministros da Coroa neutralizar a crescente influência do Parlamento nos negócios públicos (Vile, 1998:77). Ao contrário do que pretendia Bolingbroke, de um lado, e Locke, de outro, o conteúdo da antiga Constituição ou do contrato originário não tinha como ser conhecido e, ainda que o pudesse, não poderia, dado seu anacronismo, dar conta dos problemas modernos. Mais do que uma substância a ser cerimoniosamente preservada contra a mudança, a política deveria se orientar por um pragmático "espírito" prescritivo que lhe permitisse adaptar-se às circunstâncias. Daí que a defesa da imutabilidade da Constituição devesse ser substituída pelo respeito a seus "princípios históricos", e não à literalidade de suas normas medievais. Foi essa interpretação conservadora da Constituição inglesa - um governo misto cujo equilíbrio era mantido pela moderação recíproca de suas partes componentes - que se tornou predominante no decorrer do século XVIII, como se pode perceber na seguinte passagem de Blackstone (1723-1780):

Herdamos um velho castelo gótico, erigido na época da cavalaria, mas condicionado a um habitante moderno. Os muros rodeados de fossos, as torres arredondadas e as salas de troféus são magníficos e veneráveis, mas inúteis. Os apartamentos inferiores, agora convertidos em habitações úteis, são alegres e cômodos, embora os arredores sejam sinuosos e difíceis (apud Storing, 1996:594; tradução minha).

Essa rejeição à abstração como ferramenta da política afastou o constitucionalismo anglo-saxão das querelas do direito público continental. Na medida em que o consenso quanto ao fundamento histórico do poder político dispensava o recurso ao conceito de soberania, ecoaram escassamente na Inglaterra as discussões sobre o caráter absoluto ou limitado do poder que ocupavam cada vez mais espaço no debate continental. Em vez de servir de referência teórica para a modelagem de novas instituições legítimas, foi o modus operandi empírico das instituições existentes, herdadas do passado, pois, que ali orientou as interpretações elaboradas pelos atores e autores políticos acerca da natureza e do lugar do poder público. Na melhor das hipóteses, o conceito de soberania era pensado como soberania parlamentar, o que era o mesmo que dizer que, por trás da fachada da unidade soberana, estava a fragmentária realidade da constituição mista. Assim, por exemplo, embora 
reconhecesse que "em todos os governos existe e deve existir uma autoridade suprema, irresistível, absoluta, incontrolável, em que residam os jura summi imperii, ou os direitos de soberania", cujas ações "nenhum poder na terra pode desfazer", Blackstone apressava-se em frisar que a "soberania da Constituição Britânica" estava no Parlamento composto pelo rei, pelos lordes e comuns (apud Bailyn, 2003:191). Tal emasculação da soberania se refletiu no diminuto espaço reservado à discricionariedade regulada depois de 1688: a única modalidade de exercício desse poder de exceção estava na suspensão da garantia de habeas corpus. Mesmo assim, o rei era proibido de fazê-lo sem autorização do Parlamento - espaço decisório bastante aquém daqueles previstos por Maquiavel e Locke. Em síntese, era o triunfo do direito sobre o político.

Essa interpretação da Constituição britânica como equilibrada teve um impacto enorme sobre a ideia que os políticos e os filósofos continentais formaram de um governo limitado pelas leis, respeitador dos direitos de cada qual - de sorte que a via inglesa passou a gozar de grande popularidade entre os adversários do absolutismo. Por esse motivo, diversos foram os retratos que lhe fizeram autores de língua francesa, entre os quais Jean-Louis de Lolme e Burlamaqui. O mais célebre deles foi esboçado em 1748 pelo Barão de Montesquieu (1689-1755), que consagrou uma teoria que substituía o conceito de soberania pela ideia-força da moderação. De fato, nas mais de quinhentas páginas de O Espírito das Leis, a palavra soberania não é veiculada uma única vez. Nem o monarca nem o déspota são jamais qualificados por Montesquieu como soberanos. Outras expressões, como soberano ou poder soberano, são empregadas como sinônimas de poder superior, não absoluto.

A crítica ao exercício discricionário do poder recaía também sobre o tema do estado de exceção: embora reconhecesse que a salvação do povo é a suprema lei, devendo-se, em casos emergenciais, "pôr-se um véu sobre a liberdade, tal como se esconde a estátua dos deuses", Montesquieu invocava a expressão ciceroniana não para justificar o poder excepcional ou permanente do príncipe sobre os súditos, mas, ao contrário, para legitimar a resistência do povo ao tirano. Contendo a mais formidável descrição já efetuada sobre o governo republicano, com abundantes citações de Políbio, Maquiavel e Harrington, O Espírito das Leis relegava o tema da ditadura romana, todavia, a segundo plano. Para Montesquieu, tratava-se de uma instituição violenta e arriscada de que se valera a aristocracia romana contra os excessos da multidão em 
nome da liberdade, mas cujos efeitos colaterais não raro favoreciam o mal que se pretendia evitar: a tirania. "Magistraturas terríveis", a censura, a ditadura e a inquisição, empregadas em Atenas, em Roma e na Europa renascentista, não passavam de remédios anacrônicos, desmesurados e ineficazes para a preservação da liberdade (Montesquieu, 1979:34, 68 e 78). O único mecanismo de discricionariedade regulada cuja utilidade se reconhecia era justamente a suspensão temporária da garantia de habeas corpus, previsto na Constituição da Inglaterra (id., ibid.:405 e 410). Em síntese, não havia como pôr a discricionariedade a serviço da liberdade, como haviam acreditado Maquiavel e Locke. Em vez de focar elementos como soberania e exceção, a reflexão e a apologia montesquianas recaíam sobre as instituições, os procedimentos legais, o governo moderado e, sobretudo, a Constituição inglesa.

Montesquieu acreditava que, embora os homens amassem a liberdade, porque ela era necessária à satisfação de suas paixões, uma sociedade que não as limitasse haveria inevitavelmente de ser governada pelo despotismo. As diferentes respostas conferidas pelas sociedades empíricas ao problema relativo à conciliação da ordem com a liberdade permitiam estabelecer uma tipologia de três diversas formas ideais de governo, duas das quais eram "moderadas" - a república (aristocrática e democrática) e a monarquia -; e a terceira, "despótica" - o despotismo. Os tipos e subtipos de governo eram produtos de determinadas paixões humanas específicas que os sustentariam - os "princípios" de governo (ibid.:41). A virtude cívica era o princípio das repúblicas democráticas, como outrora em Esparta; ao passo que a moderação seria a base das aristocráticas, como em Veneza. A marca distintiva dos governos moderados era o pluralismo, isto é, a relativa desconcentração do poder político em mais de uma agência e/ou forças sociais. O medo difuso da população em relação ao príncipe, por sua vez, era o princípio do despotismo, regime arbitrário de um só ao redor do qual tudo era "vazio", pela inexistência de polos secundários que se lhe pudessem contrapor. O arbítrio do déspota produzia um governo que era um verdadeiro buraco negro para os tipos moderados, que, sujeitos à corrupção, tinham sempre no despotismo sua última parada (a exemplo da oclocracia platônica). Além disso, a monarquia e a república eram governos de leis, que buscavam a estabilidade pelas instituições - ao contrário do despotismo que, calcado exclusivamente na pessoa do déspota, estava sujeito aos maiores solavancos (ibid.:73).

A grande surpresa na tipologia das formas de governo montesquianas residia no tratamento conferido por Montesquieu aos conceitos de mo- 
narquia e despotismo. Até então descrita pelos absolutistas como o governo de um único, a monarquia passou a ser apresentada na conformidade do constitucionalismo antiquário: governo de um único, certo, mas nascido no feudalismo, quando o poder principesco era contrabalançado por forças sociais autônomas, como a nobreza, a Igreja e as corporações. Além delas, havia uma agência judiciária encarregada de velar pela legalidade dos atos do governo. O autor das Cartas Persas foi mais adiante ao declarar que a monarquia era a única modalidade moderna possível de governo moderado. A despeito de admirar a república, ele acreditava que, por sua aversão ao comércio e diminutos território e população, tratava-se de uma constituição anacrônica - antieconômica, de difícil implementação e manutenção. A república não sobreviveria às monarquias, de território mediano, tampouco às paixões dos homens modernos, que rapidamente a corromperiam. O governo monárquico, ao contrário, dispensava o moralismo das virtudes cívicas para exigir tão somente o respeito externo às leis, o que compatibilizava a modernidade econômica com as liberdades civis (Morilhat, 1996:27). Ausente nos demais tipos de governo, cabia ao estamento nobiliárquico filtrar os excessos do poder desde sua fonte (o rei) até seus destinatários (o povo). Por sua condição privilegiada do ponto de vista civil e sua posição estratégica entre o povo e o monarca, a nobreza e seus tribunais de justiça, os Parlements proporcionavam as condições "físicas" e sociais da liberdade da constituição monárquica. Tudo estava aí de acordo com a "voz da natureza" - a maior complexidade da estrutura política, a autonomia da sociedade em face do governo, a compatibilidade dos direitos com o progresso econômico, o esclarecimento dos homens e a lei como moderadora dos conflitos. Reconceitualizado à luz da razão, o constitucionalismo antiquário era alçado por Montesquieu à categoria de um universal, e a monarquia gótica, obra-prima do governo misto, era reputada "o melhor governo que os homens puderam imaginar" (Montesquieu, 1979:175).

Entre as monarquias de seu tempo, Montesquieu considerava a Inglaterra a mais bem-sucedida em adequar sua constituição monárquica à modernidade política e econômica. Ao descrever o funcionamento das instituições políticas inglesas, ele inovou ao sobrepor a separação dos poderes por especialização, esboçada pelo republicanismo cívico seiscentista, à estrutura do constitucionalismo antiquário de Bolingbroke (Kramnick, 1968:150). Depois de comparar a Inglaterra com a república romana, o autor de $O$ Espírito das Leis sustentava que, além da capacidade que a nobreza tinha de impedir ou filtrar o poder, o equilíbrio 
das instituições inglesas provinha também da retirada do Poder Legislativo das mãos da realeza. O poder político ficara distribuído de maneira equitativa entre os três poderios sociais do governo misto. O monarca deteria o Executivo, ao passo que o povo e a aristocracia partilhariam o Legislativo por meio de um bicameralismo - a segunda Câmara, hereditária, na forma de um Senado ou Câmara de Lordes; a primeira, eletiva, na forma de uma Câmara dos Deputados ou dos Comuns. Esse verdadeiro sistema de vetores era complementado por mecanismos de freios e contrapesos, permitindo a colisão de interesses recíprocos sem ameaçar a estabilidade sistêmica (Starobinski, 1990:90). O ponto de apoio e de equilíbrio do sistema era a Câmara Alta, isto é, o Senado, que representava a aristocracia. Porque lhe permitiam moderar e amortecer os conflitos entre rei e povo, sua hereditariedade, equidistância e neutralidade faziam do Senado o "poder regulador" do Estado (Montesquieu, 1979:151). Ao aniquilar a soberania para converter a monarquia, de tipo puro, num governo do direito e da pluralidade, Montesquieu difundiu a primeira teoria sistemática do constitucionalismo moderno, estabelecendo a Constituição inglesa como paradigma de um governo representativo.

Cerca de trinta anos depois, ao declararem sua independência, o esquema de Montesquieu seria adotado pelas treze colônias inglesas ao se organizarem como os Estados Unidos da América. Essa não foi, todavia, a trajetória do Estado de direito na Europa continental, onde, durante o século XVII, o discurso republicano e o constitucional antiquário foram esmagados pelo absolutismo.

\section{ORIGENS DO PADRÃO FRANCO-CONTINENTAL DE GOVERNO CONSTITUCIONAL: A PRECEDÊNCIA DO POLÍTICO SOBRE O DIREITO}

Na segunda metade do século XVI, estava claro para os observadores da cena política da França que a decadência do feudalismo e os conflitos religiosos haviam desequilibrado a constituição mista do país, caracterizada pela obrigação da Coroa de ouvir os conselhos de seus vassalos e respeitar os direitos históricos dos três estamentos (Skinner, 1996:533). Como na Inglaterra, a percepção de que o rei estava extrapolando os limites políticos tradicionais desencadeou reações da aristocracia, vazadas na linguagem do constitucionalismo antiquário de François Hotman (1524-1590) e do republicanismo monarcômaco de Étienne de la Boétie (1530-1563). O conflito entre absolutistas e opositores chegou ao clímax durante a Fronda, em meados do século seguin- 
te. A nobreza de toga insistiu que os Parlements tinham o direito de controlar a legalidade dos atos da realeza, enquanto, liderada pelo Príncipe de Condé (1621-1686), a nobreza de espada combateu seu progressivo alijamento dos negócios do Estado pelas armas. No entanto, o conflito teve um desfecho inverso ao da Revolução Inglesa: enquanto Carlos I (1600-1649) era decapitado em Londres, Luís XIV (1643-1715) debelou a rebelião da nobreza togada e três anos depois derrotou os aristocratas insurretos. A submissão da nobreza ao poder monárquico importou para a hegemonia do discurso absolutista, que só voltou a ser questionado quando Pierre Jurieu (1637-1713), François Fénelon (1651-1715) e o Marquês de Boulainvilliers (1658-1722) defenderam a revitalização dos órgãos representativos da nobreza no século XVIII (Jardin, 1998:17).

Nessa época, porém, a exemplo da Inglaterra, o constitucionalismo antiquário e o republicanismo clássico foram problematizados pela "nova sociedade" francesa, organizada em salões literários e em clubes públicos ou da maçonaria. No início do século XVIII, as duas ideologias estavam perdendo sua capacidade persuasiva em face de uma "consciência histórica" que, em vez de postular o retorno aos antigos princípios para regenerar o sistema político, começava a compreendê-lo a partir de uma dinâmica de emancipação racional do indivíduo diante do obscurantismo do passado. Esse posicionamento era consequência da difusão de doutrinas mais abstratas ou racionalistas, como as do jusnaturalismo contratualista, cujos fundamentos anti-históricos não guardavam compromissos com a ordem política tradicional. Essa renovação da linguagem política ocorreu em torno de 1750, quando a querela do jansenismo tornou difusa a noção de soberania nacional, e os discursos mais antigos tiveram de se adaptar sob pena de se tornarem anacrônicos. O debate progressivamente deslizou, então, do terreno eclesiástico, no qual contendiam jansenistas e magistrados, para o do judiciário, em torno da necessidade de se fortalecerem os Parlements, para chegar finalmente ao terreno constitucional, desencadeando uma crise de legitimidade do regime absolutista. Ultrapassando os limites impostos pelo Estado, a luta política extravasou para os cafés, clubes e salões, de onde sairia para ganhar as ruas. Os novos discursos de oposição eram calçados respectivamente na justiça - constitucionalismo antiquário -, na razão - despotismo ilustrado - e na vontade - republicanismo democrático (Baker, 1990:25). Elaboraram-se assim três novas concepções sobre o político. Abraçado pela nobreza togada, o primeiro deles enfatizava uma concepção judiciarista, ao passo que, de- 
senvolvida pelos fisiocratas, herdeiros do despotismo ilustrado, a segunda ideologia traduzia uma concepção administrativa. A última vertente sublinhava uma concepção voluntarista do político, postulada pela tradição republicana depois da incorporação de elementos do jusnaturalismo contratual.

O constitucionalismo antiquário francês ressurgiu nos primeiros anos do século, quando os historiadores germanistas postularam a limitação do poder monárquico em benefício da aristocracia. $\mathrm{O}$ argumento era o de que, descendente dos invasores francos, a nobreza gozaria hereditariamente dos direitos decorrentes da conquista. A ordem política legítima corresponderia a uma constituição que, aperfeiçoada no período gótico, consagrava um governo misto em que o rei governava com o consentimento dos estamentos (Baker, 1990:38). Como depositários das leis editadas pela Coroa, pertenceria aos Parlements, isto é, aos tribunais aristocráticos, o direito de verificar sua conformidade com aquela constituição antes de registrá-las e de devolvê-las em caso negativo. Reconhecer a autoridade dos tribunais aristocráticos para exercer um controle da constitucionalidade das leis implicava negar a própria soberania absoluta do monarca. No entanto, o constitucionalismo antiquário foi o discurso mais duramente atingido pela nova moldura intelectual do setecentismo francês. Como na Grã-Bretanha, ele foi articulado com o objetivo de inferir, do estudo da história nacional, a existência de uma constituição imemorial que imporia limitações aos poderes absolutos da Coroa e de comprovar que determinados órgãos de interesses corporativos, representativos de segmentos sociais, eram tão ou mais antigos que a própria realeza, e por isso lhe equivaliam ou lhe precediam. Contudo, havia uma diferença. Do outro lado da Mancha, a instituição beneficiária desse discurso - o Parlamento contemplava tanto os interesses da nobreza quanto dos comuns, ao passo que, na França, a instituição prestigiada pelo constitucionalismo antiquário não eram os Estados Gerais, órgão representativo da nação desativado desde 1614. Os antiquários franceses valorizavam justamente os Parlements, corporações nobiliárquicas cujos cargos eram patrimonialmente adquiridos e hereditariamente transmitidos. Os tribunais aristocráticos eram apresentados pelos antiquários como representantes da nação, e os nobres que os compunham, campeões da liberdade contra o "despotismo ministerial". Além disso, embora a aristocracia inglesa ocupasse corporativamente uma Câmara política, ela não constituía mais estamento civil privilegiado, ao contrário da nobreza francesa. 
Com sua recusa de equiparar-se civilmente ao restante da população, o intento antiquário de recuperar os "antigos direitos" políticos da nobreza prejudicou largamente sua capacidade de se tornar hegemônico, sobretudo porque a emergência das novas camadas sociais do Terceiro Estado a cada dia tornava mais anacrônica a divisão estamental entre nobreza, clero e povo. Em decorrência disso, o desapreço por soluções que implicassem recorrer à história e o ódio aos privilégios nobiliárquicos inviabilizaram o êxito de uma campanha que valorizasse a conversão da monarquia absoluta num governo misto ou numa constituição equilibrada à inglesa, o que forçosamente passaria pela criação de uma Câmara aristocrática. Inviabilizado o consenso em torno da reivindicação do poder pelo povo, outros setores sociais começaram a buscar uma fórmula que extirpasse a fragmentação política que o constitucionalismo antiquário só viria a aprofundar entre a nobreza e o Terceiro Estado. Propostas de reformas pluralistas, em que mecanismos como a divisão dos poderes e os freios e contrapesos equilibrassem as partes integrantes da constituição, tendiam a ceder lugar a outras que, em vez de desconcentrar o poder político, pretendiam, na esteira da tradição absolutista, concentrá-lo exclusivamente na nação, em que o corpo político fraturado poderia reencontrar sua unidade perdida. Nesse sentido, por mais diferentes que fossem, tanto o despotismo esclarecido quanto o republicanismo sofreram a influência do discurso totalizante do absolutismo. A sedimentação de seus conceitos basilares de poder - sobretudo o de soberania absoluta - os levou a reconhecer que a "antiga Constituição" francesa, se é que existira, havia de todo desaparecido, e que não era mais possível nem desejável retornar ao passado. Rejeitando a ideia de que o bem político poderia emergir da adequada oposição e equilíbrio dos vícios privados, a intelectualidade iluminista inclinou-se a crer que cabia à razão e à vontade a tarefa de, criticando a história como matriz de preconceitos e injustiças, forjar uma nova ordem política, capaz de proporcionar a felicidade geral.

A crítica dos adeptos do despotismo ilustrado à obra de Montesquieu e às suas teorias de governo moderado era evidência mesma da aversão dos philosophes às suas conclusões antiquárias. Para Helvétius (1715-1771) e para Voltaire (1694-1778), O Espírito das Leis fornecera novas justificativas para que os inimigos do interesse público resistissem ao poder unificador da realeza e defendessem um poder político fragmentado, que só beneficiava os estamentos e as corporações. Nos Comentários Políticos, depois de comentar ser "uma ideia bem vã, um tra- 
balho bem ingrato, o de querer tudo remontar aos usos antigos, e de querer fixar essa via a que o tempo confere um movimento irresistível", Voltaire atacava o constitucionalismo antiquário como um meio engenhoso por que a nobreza tentava "revestir de algum brilho a torpeza de sua origem" (2001:202 e 69). Em "Do Espírito", Helvétius (1973b) criticava a Constituição inglesa como má e irracional, verdadeira anarquia de interesses particulares. A pretendida restauração da monarquia gótica, restabelecendo o poderio feudal da nobreza, interromperia todo o progresso racional adquirido pelo movimento das $\mathrm{Lu}$ zes. A experiência francesa comprovara que um poder absoluto, fora do alcance das facções e das paixões, era a única força capaz de vencer a resistência da nobreza e de criar um polo alternativo aos interesses privados, em torno do bem comum. Era o que ele vaticinava em suas "Cartas sobre o Espírito das Leis": somente "enfraquecendo a estúpida veneração dos povos pelas leis e usos antigos", os soberanos se poriam "em condição de purgar a terra da maioria dos males que a desolam" (Helvétius, 1973a:225). Por isso, em vez de desconcentrar o poder, as reformas deveriam elevar a potência discricionária do monarca e orientá-lo a agir conforme as leis da natureza para que ele pudesse esmagar mais prontamente os focos feudais remanescentes representados pelo clero e pela aristocracia e forjar uma nova ordem, em que os direitos individuais fossem respeitados. Daí que "um rei verdadeiramente bom é o mais belo presente que o céu pode oferecer à terra" (Voltaire, 2001:81). Tentativa de compatibilizar o absolutismo com a emancipação do indivíduo e o progresso histórico, o despotismo ilustrado constituiu a matriz do pensamento fisiocrático que, a partir da década de 1770, com o ministro Robert Jacques Turgot (1727-1781), buscou o apoio da Coroa para a implementação de uma "monarquia cesarista que concedesse e garantisse aos cidadãos liberais um espaço correspondente às suas reivindicações" (Koselleck, 1999:123). Embora se reconhecesse que a soberania cabia não ao rei, mas à nação, a Coroa continuava a ocupar o lugar central da representação política. Na qualidade de principal defensor do interesse público, caberia ao Executivo, detentor da técnica administrativa, julgar da conveniência e da oportunidade dos interesses que se pretendiam representar nas assembleias eletivas de representantes (Schmitt, 1968:148).

Embora também tenha sofrido com a emergência da filosofia do progresso, o discurso republicano francês (o chamado republicanismo clássico) mostrou maior capacidade de adaptação aos novos tempos do que o constitucionalismo antiquário. Sua maior maleabilidade lhe permitiu agregar ao discurso clássico elementos modernos, como o jusnatu- 
ralismo contratual e o conceito de soberania nacional, tornando-o atraente aos profissionais liberais, que estavam descomprometidos tanto com o absolutismo quanto com a aristocracia. Os três principais autores republicanos foram Jean-Jacques Rousseau (1712-1778), Gabriel Bonnot de Mably (1709-1785) e Guillaume-Joseph Saige (1746-1804). Mably adentrou na querela franco-gálica para desmistificar o papel da nobreza e da Coroa, ao passo que Rousseau preferiu justificar seu ponto de vista a partir de uma reconstrução histórica racional e universalista. Saige, por ser turno, lançou mão de ambos os expedientes, que já se encontravam à sua disposição. Embora houvesse acordo a respeito do modo como o poder político deveria ser exercido pelo povo, quando se consolidaram os novos elementos ideológicos, na segunda metade do século, já se encontrava elaborado "um republicanismo especificamente gálico focado em três bases: soberania nacional, direito como expressão da vontade geral e separação de poderes" (Wright, 2002:297 e 304). Se, a exemplo de Helvétius e de Voltaire, os republicanos também rejeitavam o resgate de constituições históricas, o fato é que eles também repudiavam o despotismo ilustrado defendido pelos primeiros, que lhes parecia tão bizarro quanto a monarquia gótica montesquiana ou a Constituição inglesa, com seus estamentos e mecanismos de freios e contrapesos. Em obras como Dos Direitos do Homeme do Cidadão, de Mably; O Contrato Social, de Rousseau; e Catecismo do Cidadão, de Saige [1787], os republicanos democratas priorizavam o restabelecimento das liberdades públicas, e não a detestável modernização perseguida pelos fisiocratas, que corrompiam as virtudes cívicas. Para melhor combater o absolutismo monárquico, eles se apropriaram do conceito de soberania e entregaram-no ao povo. Fruto da livre associação humana, a soberania popular era absoluta e, como tal, indivisível e intransferível, detendo o povo o direito de fazer e de desfazer o governo, independentemente de sua natureza e qualidade (Mably, 1789:26). Expressões da vontade geral, suas leis eram obrigatórias, gerais e impessoais (Rousseau, 1997a:91). O contratualismo terminava por proclamar que todos os homens nasciam livres e iguais para perseguirem o bem-estar e a felicidade e associavam-se em igualdade de condições para submeterem-se a um governo de leis elaboradas por si ou por seus representantes (Mably, 1789:3). Os cidadãos não estavam sujeitos a nenhuma vontade pessoal ou arbitrária, pois o dever de submissão era correlato à liberdade política (Rousseau, 1997a:70).

A terceira característica do discurso republicano - a separação de poderes - é conexa à sua concepção unitária da soberania e à crítica das 
noções inglesas de equilíbrio institucional. É que os republicanos recusavam a distinção do mundo social entre esfera pública e esfera privada, partilhada por anglófilos e fisiocratas. Para autores como Hume e Montesquieu, o reconhecimento da autonomia de cada uma dessas esferas contribuíra para relativizar as relações entre vícios privados e virtudes públicas, conciliando os imperativos de progresso econômico e de liberdade civil. O republicanismo francês acreditava, ao contrário, na profunda interdependência entre público e privado, porque concebia a esfera social de maneira indivisível, como a própria soberania, e julgava a liberdade política incompatível com a econômica. Porque a corrupção dos costumes privados se refletia diretamente nos costumes públicos, esses autores exigiam que a virtude reinasse tanto no óikos quanto na ágora. Essa concepção antimoderna do político e do econômico, que os levava a ridicularizar os philosophes e sua defesa dos "progressos da civilização", levavam-nos a suspirar pelo restabelecimento de leis suntuárias e a louvar o comunismo espartano elogiado por Platão (Mably, 1789:173). Eles acreditavam que o comércio e o luxo, levando ao desenvolvimento das ciências e das artes, eram os grandes responsáveis pela corrupção reinante nas sociedades de seu tempo. A modernidade econômica favorecia o pluralismo e o universalismo, elementos dissolventes do amor à pátria; fomentava as desigualdades e os vícios, que tornavam os homens mais egoístas e isolados em seus interesses (Baker, 1990:36). Ao esposar a tese de que a comunidade possuía um poder absoluto e exclusivo sobre si mesma, a concepção moralista de espaço público defendida pelos republicanos democratas resultou na rejeição do modelo político inglês descrito por Montesquieu, condenado como incapaz de assegurar o primado da virtude pública. A Constituição inglesa legitimava a ação nefasta das facções ao fundar sua estabilidade sobre os interesses privados e elevar a corrupção à categoria de qualidade cívica. Tendo como pilares a verdade e a virtude, a organização da república democrática deveria se caracterizar por uma simplicidade que, refletindo a tradição absolutista da unidade, fosse proporcional aos costumes de seus cidadãos (Rousseau, 1997b:229). Essa concepção das relações público-privadas, da soberania e da representação conduziu ao projeto de um arcabouço institucional que, se admitia a divisão dos poderes, recusava as noções de equilíbrio, moderação e interdependência (Gauchet, 1995:58); e, por via reflexa, a tradição clássica do governo misto, eminentemente plural. O poder de exprimir vontade e decisão, marca da soberania, deveria ser expresso pelo povo reunido em pessoa ou numa assembleia úni- 
ca de representantes, excluída do processo legislativo a participação de uma segunda Câmara.

Além disso, ainda que os republicanos democratas admitissem que o cumprimento das decisões devesse recair sobre órgão diverso do Legislativo - o governo -, daí não se seguia que ele deveria ser autônomo. A representação da comunidade política pelo governante era associada pelos republicanos democratas ao processo histórico de construção do absolutismo e, por isso, imaginavam que a mera existência de um governo autônomo bastava para usurpar a soberania do povo. Para Rousseau e Mably, a existência de privilégios políticos ou hereditários induzia ao patrimonialismo; ademais, o exercício do governo pelos dirigentes não decorria do direito próprio dos magistrados: eles eram meros funcionários, procuradores ou administradores do povo soberano. A solução passava: ou pela eliminação pura e simples da representação pela prática de uma democracia direta, na qual o soberano se exprimisse junto ao governo sem intermediários (Schmitt, 1968:273); ou pela transferência desse papel de representação existencial a uma assembleia de eleitos, sobre a qual o povo manteria constante vigilância, por meio de órgãos de fiscalização e controle. Depositária do poder soberano, a assembleia passaria a representar a unidade do corpo político, tarefa até então exercida pelo rei. O segredo da boa república estava em distinguir entre governo e soberano, entre execução e decisão, subordinando o primeiro ao segundo de tal sorte que, destituído da vontade de querer, acabasse reduzido à condição de seu apêndice. A aniquilação do Poder Executivo enquanto personificação visível e simbólica da sociedade política constituía mesmo "o pináculo da perfeição política" (Mably, 1789:337). As providências destinadas a efetivar a contento essa subordinação eram as seguintes: primeiro, desfazer a unidade do Poder Executivo fracionando-o em número correspondente ao de pastas ministeriais exigidas pelos negócios públicos. Em segundo lugar, os postos ministeriais seriam ocupados por magistrados escolhidos pela assembleia, diretamente ou por meio de listas. Longe de constituir um gabinete, cada um deles seria o único responsável perante a assembleia pela própria pasta, sem qualquer vínculo com os demais ministros. Por último, ele não disporia de nenhuma participação no processo legislativo. Sem direito de iniciativa nem de veto, cumpria ao governo somente executar as decisões da vontade geral, expressas pelo Legislativo.

Os republicanos democratas entenderam, todavia, que semelhante organização não bastava para assegurar o primado da virtude e a conser- 
vação da república. Era vasta a gama de seus inimigos: havia os externos, como outros países, o comércio e o luxo; os internos, como facções, magistrados e cidadãos ímprobos; e havia a própria natureza humana, sujeita a naturalmente corromper-se. Sem um esforço permanente de virtude para compensar os efeitos da fortuna, o tempo traria a corrupção e, com ela, a perda da liberdade. Para contrabalançar tais efeitos, o receituário republicano envolvia duas medidas: a difusão de um amplo sistema de educação que generalizasse o amor à pátria e a liderança de políticos virtuosos que, a exemplo de Licurgo e Sólon, propusessem leis sábias e servissem como modelos de civismo. Os legisladores deveriam guiar o povo não para substituírem sua vontade à deles, mas para levá-lo a encontrar o que desejava sem conseguir exprimi-lo, ou seja, para exprimir e cumprir sua vontade (Rousseau, 1997a:109). Para além desses meios de profilaxia, a república deveria criar magistraturas que, inspiradas na Antiguidade clássica, pairassem sobre os poderes ordinários, tendo por características a independência diante de órgãos do Estado que deveriam inspecionar; a responsabilidade exclusiva perante o povo; e o exercício de certo poder discricionário. É que a conservação da república passava, ao mesmo tempo, pela preservação da eficácia das leis e dos costumes, na forma fixada pela vontade geral, e pela possibilidade de sua eventual suspensão, quando o soberano estivesse ameaçado. São três as instituições que merecem nossa atenção: ditadura, tribunato e censura.

A ditadura não apenas fazia aqui sua reentrada como servia de referência às outras instituições, graças à sua longeva tradição. Segundo Rousseau, o governo ditatorial surgia da impossibilidade de previsão legal das eventualidades da fortuna e da necessidade de salvar a república em ocasiões de grave e iminente perigo. Quando a ameaça não exigisse o completo "adormecimento das leis", haveria uma concentração administrativa do Executivo nas mãos de um ou dois magistrados (id., ibid.:225). Entretanto, se a ameaça fosse premente e de monta, a assembleia nomearia uma autoridade suprema que concentrasse os poderes e suspendesse as leis na forma de uma ditadura comissariada. Nesse ponto, havia divergências entre os dois principais autores republicanos franceses, sendo a cautela legalista de Mably proporcional à sua desconfiança em relação ao radicalismo de Rousseau. Embora reconhecesse que a necessidade requeria, por vezes, o regime discricionário, Mably contemplou apenas a hipótese de invasão estrangeira e só quando esgotados os demais meios de salvação pública. Extintas as causas que lhe deram origem, o Legislativo deveria imediatamente en- 
cerrar a ditadura e restabelecer o quadro constitucional para evitar que "vias extraordinárias, à força de usá-las [...] se convertam em vias ordinárias" (Mably, 1789:357). Apesar de constatar a imprescindibilidade de prazos curtos e preestabelecidos, para Rousseau era impossível definir juridicamente todas as hipóteses de autossuspensão do ordenamento jurídico para as ditaduras (1997a:226). Embora preocupado em regular as hipóteses do estado de exceção, Rousseau reconhecia, nas Considerações sobre o Governo da Polônia, o direito permanente da vontade geral de modificá-las independentemente de qualquer ordem ou previsão legal, pois a soberania era matéria de fato, não de direito (1982:69). No melhor estilo maquiaveliano, Rousseau destacava a utilidade daquela instituição quando a ordem republicana enfrentasse dificuldades relativas à consolidação de suas instituições, acenando com exemplos da história romana (1997a:226).

As duas outras instituições de poder discricionário regulado visavam também à conservação da república. Se a ditadura prevenia sua destruição imediata, as outras investiam contra a corrupção, que, gerada pela inobservância das leis e dos costumes, a destruía a longo prazo. Do combate à ineficácia da legislação ficaria incumbido um órgão que, não designado por Mably, é chamado por Rousseau de tribunato; já os costumes seriam preservados por um Tribunal de Censura. Na medida em que a corrupção dos costumes era pressuposto da ineficácia das leis, de nada adiantava editar leis novas para combater o mal. O que precisava ser atacado estava na raiz, pois eram "os pequenos abusos que abrem a porta às maiores desordens" (Mably, 1789:352; tradução minha). Daí a importância de instituições que, compensando a força corrosiva da fortuna, velassem para que a observância dos costumes e das leis se mantivesse em patamar elevado. Para justificá-las, os autores invocavam novamente a fraqueza humana, a força corruptora da inércia e a incapacidade de previsão legal de todas as contingências que, na vida pública, levavam ao enfraquecimento da virtude, ao relaxamento dos costumes e à frouxidão das leis - justificativas que desvelam seu parentesco com o instituto da ditadura. Para Rousseau, a Censura era o órgão ordinário encarregado de manter os costumes na conformidade dos hábitos consagrados pelo povo, "impedindo as opiniões de se corromperem, conservando a sua retidão por meio de aplicações sábias e até, algumas vezes, fixando-os, quando ainda se mostram incertos" (Rousseau, 1997a:230). Essa corte teria três importantes atribuições: zelar pela execução das leis suntuárias, coibindo o luxo em nome de uma "simplicidade cômoda"; supervisionar os estabeleci- 
mentos de instrução pública a fim de garantir uma educação da mocidade conforme os princípios republicanos; e proteger os "cidadãos fracos, que às vezes não ousam ou não podem queixar-se da tirania de um cidadão rico ou prestigiado". Os censores deviam ser eleitos pelos legislativos provinciais para mandatos curtos, encaminhando sugestões ao Legislativo nacional (Mably, 1789:319 e 322).

Apesar de Rousseau batizar o tribunato com o nome de uma antiga instituição romana, ambas pouco tinham de semelhantes. Abandonado o modelo republicano tradicional de governo misto por um regime de supremacia unicameral, Rousseau pretendia aproveitar a experiência dos éforos de Esparta, do tribunato romano e do conselho veneziano dos dez órgãos para modelar uma instituição que não apresentasse os mesmos defeitos e mantivesse a estabilidade da república de forma diversa do antigo Senado. Ele imaginava um terceiro corpo político que mantivesse o governo dentro dos limites estipulados pela vontade geral, coordenando as demais magistraturas e restabelecendo as leis violadas. Por isso mesmo, o tribunato não poderia se confundir com as instituições que ele deveria moderar ou proteger. Uma vez que esse órgão tinha o dever de coibir as ações nocivas dos demais, ou seja, tinha um papel essencialmente passivo ou negativo, o perigo estava em que ele se portasse como um poder ativo ou positivo e usurpasse as atribuições alheias em vez de moderar o governo e proteger o legislativo. A melhor maneira de evitar que isso ocorresse era não fazer desse "corpo tão temível" por sua discricionariedade uma instituição permanente, mas sim bissexta, isto é, periódica. Poder extraordinário, portanto, esse órgão conservador das leis "sabiamente equilibrado" seria "o mais firme apoio de uma boa constituição" (Rousseau, 1997a:221-222) e, como tal, o mais reverenciado da república. Mably também previu um órgão como esse, nos mesmos moldes, imaginando uma ditadura corregedora de caráter extraordinário e periódico encarregada de examinar a legalidade dos atos governamentais. Como o autor de Dos Direitos e Deveres do Cidadão não acreditava que a educação, o governo e os legisladores fossem capazes de combater os males da degenerescência, ele sugeria que, a cada vinte ou vinte e cinco anos, a assembleia instalasse um comitê extraordinário de poderes discricionários que verificasse se os governantes haviam exorbitado e apurasse os atentados às leis. Mably tinha a esperança de que "essa sábia precaução impediria que costumes novos se difundissem e todos os abusos seriam reprimidos antes de adquirirem força o bastante para destruir os princípios do governo". Além disso, esse poder corregedor supremo seria "a espe- 
rança dos bons cidadãos, sendo capaz de conter os maus. Ele excitaria em todos os espíritos uma fermentação útil e, forçando a recordação das leis, impediria que elas caíssem no esquecimento" (Mably, 1789:356; tradução minha).

\section{CONCLUSÃO}

No fim do século XVIII, estavam já esboçadas as duas vias pelas quais, a partir da modelagem dos modelos anglo-saxão e franco-continental, o constitucionalismo e o tema da excepcionalidade caminhariam nos séculos seguintes. A tarefa mais difícil seria, assim, encontrar uma fórmula institucional que permitisse conciliar a dimensão absoluta do fundamento do poder político, a soberania da Nação ou do povo, com a exigência de sua própria limitação jurídica, a fim de preservar os direitos fundamentais. Entre Rousseau e Montesquieu, mas também com Rousseau e Montesquieu, essa terceira via seria tentada pelo desenvolvimento dessas reflexões, durante as revoluções Americana e Francesa.

Com efeito, a maior parte do repertório conceitual que concorreu para a elaboração da constituição norte-americana de 1787 foi extraída do acirrado debate que teve lugar na Inglaterra durante a primeira metade do século XVIII. Capitaneado por Bolingbroke na década de 1720 contra o discurso liberal emergente, o republicanismo cívico voltou com força total quarenta anos depois, quando Jorge III ascendeu ao trono e enfim a oligarquia whig foi desalojada do poder. O retorno dos tories aos conselhos da Coroa deu a muitos whigs a oportunidade de reencontrar seu antigo cânone radical, abandonado pelos novos donos do poder. Dessa vez, porém, o discurso radical foi também revestido da série de argumentos jusnaturais e contratualistas articulados por Locke para fundamentar a legitimidade da ordem política. Nessa qualidade, o republicanismo foi reivindicado pelos que condenavam qualquer concepção de governo restritiva de direitos políticos e, por isso, postulavam reformas profundas, que só teriam lugar em 1832 (Pocock, 1985:258). Essa tradição republicana revelou-se, na década de 1760, vivíssima nas colônias inglesas da América do Norte. O constitucionalismo antiquário foi outra fonte em que foram beber os fundadores da república norte-americana para justificar a submissão e a limitação do político ao direito (Bailyn, 2003:49). No entanto, o caráter fundacional decorrente da independência das treze colônias impôs importantes diferenças em face da experiência inglesa institucional, inclusive no conceito de Constituição. Num futuro trabalho, pretendo, partindo das es- 
truturas discursivas referidas na terceira seção - “Origens do Padrão Anglo-Saxão de Governo Constitucional: A Teoria da Constituição Equilibrada e a Precedência do Direito sobre o Político" -, destacar alguns dos elementos de ruptura e de continuidade verificados nesse momento, dentro da tradição anglo-americana de soberania e de governo constitucional, que desaguará no controle normativo e jurisdicional de constitucionalidade das leis.

Tendo desaparecido na Inglaterra juntamente com o absolutismo, na França, porém, a discricionariedade subsistiu no ventre do governo constitucional e representativo. Irradiado para o mundo ibero-americano nas primeiras décadas do século XIX, o fracassado modelo constitucional de 1791 trouxe um defeito congênito: a confrontação nua e crua entre um Estado limitado pela lei e a soberania absoluta do povo, sem que ele dispusesse de mecanismos de conciliação. Durante todo o período revolucionário, atores e teóricos se debruçaram sobre o problema, imaginando soluções que evitassem que os representantes extrapolassem os mandatos outorgados pelos representados; no entanto, a persistência de concepções soberanistas do poder - na forma de uma democracia das ruas ou de uma representação política absolutista mostrou-se inquebrantável. A persistência do tema do controle da constitucionalidade durante todo o período é evidência, contudo, de que os revolucionários queriam um tipo de mecanismo institucional que a lógica política que os governava em função dos acontecimentos os impedia de ter (Gauchet, 1995:121). A compreensão de que os descaminhos da Revolução decorriam da incongruência entre seus princípios e uma organização política capaz de concretizá-los, para além do estado de exceção, seria o que motivaria os liberais a tentar atenuar os excessos do modelo republicano. Eles desenvolveram então uma fórmula de salvaguarda do governo constitucional, não normativo-jurisdicional, mas político-estrutural, na forma de um órgão de cúpula neutro, distinto e superior, capaz de representar e conferir visibilidade simbólica ao poder soberano - o poder neutro, preservador ou moderador. Difundido no início da Restauração, essa forma continental conciliatória de Estado e soberania cedo foi incorporada ao patrimônio intelectual ibero-americano, tendo impacto direto nas monarquias constitucionais portuguesa, espanhola e brasileira (Lynch, 2005).

(Recebido para publicação em janeiro de 2009)

(Reapresentado em outubro de 2009)

(Aprovado para publicação em janeiro de 2010) 


\section{REFERÊNCIAS BIBLIOGRÁFICAS}

AQUINO, São Tomás de. (1995), Escritos Políticos [trad. de Francisco Benjamin de Souza Neto]. Petrópolis, RJ, Vozes.

ARISTÓTELES. (1997), Política [trad. de Mário da Gama Kury]. Brasília, Editora UnB.

BAILYN, Bernard. (2003), As Origens Ideológicas da Revolução Americana. Bauru, SP, Edusc.

BAKER, Keith Michael. (1990), Constituição, in F. Furet (org.), Dicionário Crítico da Revolução Francesa [trad. de Henrique de Araújo Mesquita]. Prefácio de José Guilherme Merquior. Rio de Janeiro, Nova Fronteira.

BEAUD, Olivier. (1994), La Puissance de l'État. Paris, PUF.

BERCOVICI, Gilberto. (2008), Soberania e Constituição: Para uma Crítica do Constitucionalismo. São Paulo, Quartier Latin.

BIGNOTTO, Newton. (2001), Origens do Republicanismo Moderno. Belo Horizonte, Ed. UFMG.

. (2006), Republicanismo E Realismo: Um Perfil de Francesco Guicciardini. Belo Horizonte, Ed. UFMG.

BODIN, Jean. (1993) [1583], Les Six Livres de la République. Edição e apresentação de Gérard Mairet. Paris, Le Livre de Poche.

BOLINGBROKE, Henry St. John. [1738], “The Idea of a Patriot King”. Disponível em http:// socserv2.socsci.mcmaster.ca/ econ/ugcm/3113/bolingbroke/king.html. Acessado em 20 de janeiro de 2007.

DICKINSON, H. T. (2002), The British Constitution, in H. T. Dickinson (ed.), A Companion to Eighteenth Century England. London, Blackwell Publishers.

FATOVIC, Clement. (2004), Constitutionalism and Contingency: Lockes Theory of Prerogative. History of Political Thought, vol. 25, no 2, pp. 276-297.

FILMER, Sir Robert. (1991) [1648], Patriarcha and Other Writings [editado por Johann Sommerville]. Cambridge, Cambridge University Press.

GAUCHET, Marcel. (1995), La Révolution des Pouvoirs. La Souveraineté, le Peuple et la Représentation. Paris, Gallimard.

HELVÉTIUS, Claude-Adrien. (1973a), "Cartas de Helvétius sobre O Espírito das Leis" [trad. de Mary Amazonas Leite de Barros e Hélio Leite de Barros], in E. B. Condillac, C.-A. Helvétius e M.-J. Degérando, Textos Escolhidos [diversos tradutores]. São Paulo, Abril Cultural. (Coleção Os Pensadores).

(1973b), "Do Espírito" [trad. de Nélson Aguilar], in E. B. Condillac, C.-A. Helvétius e M.-J. Degérando, Textos Escolhidos [diversos tradutores]. São Paulo, Abril Cultural. (Coleção Os Pensadores).

HIRSCHMAN, Albert. (2001) [1977], Les Passions et les Intérêts: Justifications Politiques du Capitalisme avant son Apogée [trad. de Pierre Andler]. Paris, PUF.

HOBBES, Thomas. (1998) [1642], Do Cidadão ou Rudimentos de Filosofia Concernentes ao Governo e à Sociedade [trad. de Renato Janine Ribeiro]. São Paulo, Martins Fontes. 
. (2001) [1668], Behemoth ou o Longo Parlamento [trad. de Eunice Ostrensky]. Belo Horizonte, Ed. UFMG.

HUME, David. (1984), “Ensaios Morais, Políticos e Literários", in G. Berkeley e D. Hume, Os Pensadores: George Berkeley e David Hume [trad. de Antônio Sérgio, Leonel Vallandro, João Paulo Gomes Monteiro e Armando Mora d‘Oliveira]. São Paulo, Abril Cultural. (Coleção Os Pensadores).

JARDIN, André. (1998) [1985], Historia del Liberalismo Político. De la Crisis del Absolutismo a la Constitución de 1875 (2a ed.). México, Fondo de Cultura Económica.

KANTOROWICZ, Ernst H. (1998) [1957], Os Dois Corpos do Rei. Um Estudo sobre Teologia Política Medieval. São Paulo, Companhia das Letras.

KOSELLECK, Reinhart. (1999), Crítica e Crise: Uma Contribuição à Patogênese do Mundo Burguês [trad. de Luciana Villas-Boas Castelo Branco]. Rio de Janeiro, Contraponto.

KRAMNICK, Isaac. (1968), Bolingbroke and his Circle. The Politics of Nostalgia in the Age of Walpole. Cambridge, MA, Harvard University Press.

LOCKE, John. (1998) [1689], Dois Tratados sobre o Governo [trad. de Julio Fischer]. Introdução de Peter Laslett. São Paulo, Martins Fontes.

LYNCH, Christian Edward Cyril. (2005), “O Discurso Político Monarquiano e a Recepção do Conceito de Poder Moderador no Brasil (1822-1824)". DADOS, vol. 48, no 3, pp. 611-654.

MABLY, Gabriel Bonnot, Abbé de. [1789], Des Droits et Devoirs du Citoyen. Paris.

MADDOX, Graham. (1989), “Constitution”, in T. Ball, J. Farr e R. Hanson (eds.), Political Innovation and Conceptual Change. Cambridge, Cambridge University Press.

MAQUIAVEL, Nicolau. (1994) [1517], Comentários sobre a Primeira Década de Tito Lívio. Brasília, Editora UNB.

MEINECKE, Friedrich. (1973), L'Idée de Raison d'État dans l'Histoire des Temps Modernes [trad. de Maurice Chevalier]. Genève, Librairie Droz.

MONTESQUIEU, Charles-Louis de Secondat, Barão de la Brède et de. (1979) [1750], Do Espírito das Leis [trad. de Fernando Henrique Cardoso e Leôncio Martins Rodrigues]. Introdução e notas de Gonzague Truc. São Paulo, Abril Cultural.

MOREL, Henri. (2003), "Absolutisme", in P. Raynaud e S. Rials (eds.), Dictionnaire de Philosophie Politique. Paris, PUF.

MORILHAT, Claude. (1996), Montesquieu: Politique et Richesses. Paris, PUF.

MORRALL, John. (2000), Aristóteles [trad. de Sérgio Duarte]. Brasília, Editora UnB.

PISTONE, Sérgio. (1998), "Razão de Estado”, in N. Bobbio, N. Matteucci e G. Pasquino (orgs.), Dicionário de Política (11a ed.). Brasília, Editora UnB.

POCOCK, John. (1985), "The Varieties of Whiggism from Exclusion to Reform: A History of Ideology and Discourse", in J. Pocock, Virtue, Commerce, and History: Essays on Political Thought and History, Chiefly in the Eighteenth Century. Cambridge, Cambridge University Press.

. (1997), Le Moment Machiavélien: La Pensée Politique Florentine et la Tradition Républicaine Atlantique [trad. do inglês de Luc Borot]. Paris, PUF. 


\section{Christian Edward Cyril Lynch}

. (2003), Linguagens do Ideário Político [trad. de Fabio Fernandez]. São Paulo, Edusp.

POLÍBIO. (1996) [130?], História [trad. de Mário da Gama Kury]. Brasília, Editora UnB.

RIBEIRO, Renato Janine. (2001), "A Mídia dos Dezessete”, in T. Hobbes, Behemoth ou o Longo Parlamento [trad. de Eunice Ostrensky]. Belo Horizonte, Ed. UFMG.

RICHELIEU, Cardeal e Duque de (Armand-Jean du Plessis). (1959), Testamento Político. São Paulo, Atena Editora.

RORTY, Richard. (1984), "The Historiography of Philosophy: Four Genres", in R. Rorty, J. B. Schneewind e Q. Skinner (eds.), Philosophy in History. Cambridge, Cambridge University Press. (Ideas in Context).

ROUSSEAU, Jean-Jacques. (1982) [1771], Considerações sobre o Governo da Polônia e sua Reforma Projetada [trad. de Luiz Roberto Salinas Fortes]. São Paulo, Brasiliense.

. (1997a) [1757], Do Contrato Social [trad. de Lourdes Santos Machado]. São Paulo, Nova Cultural.

. (1997b) [1750], Discurso sobre a Ciência e as Artes [trad. de Lourdes Santos Machado]. São Paulo, Nova Cultural.

SAIGE, Guillaume-Joseph. [1787], Catéchisme du Citoyen ou Elements du Droit Publique Français, par Démandes et Réponses. Suivi des Fragments Politique. Genebra.

SAINT-BONNET, François. (2001), L'État d'Exception. Paris, PUF.

SCHMITT, Carl. (1968) [1922], La Dictadura. Desde los Comienzos del Pensamiento Moderno de la Soberanía hasta la Lucha de Clases Proletaria [trad. do alemão de José Diaz Garcia]. Madrid, Revista de Occidente.

SENELLART, Michel. (1989), Machiavélismeet Raison d'État XIIe-XVIIIe Siècle. Paris, PUF.

SIDNEY, Algernon. (1996) [1683], Discourses Concerning Government. Edição de Thomas West. Indianapolis, Liberty Fund.

SKINNER, Quentin. (1996) [1978], Os Fundamentos do Pensamento Político Moderno [trad. de Renato Janine Ribeiro e Laura Teixeira Motta]. São Paulo, Companhia das Letras.

. (1999), Liberdade Antes do Liberalismo [trad. de Raul Fiker]. São Paulo, Editora da Unesp.

STAROBINSKI, Jean. (1990), Montesquieu [trad. de Tomás Rosa Bueno]. São Paulo, Companhia das Letras.

STORING, Herbert J. (1996), “William Blackstone (1723-1780)”, in L. Strauss e J. Cropsey (comps.). Historia de la Filosofía Política. México, Fondo de Cultura Económica.

VILE, M. J. C. (1998), Constitutionalism and the Separation of Powers (2a ed.). Indianapolis, Liberty Fund.

VOEGELIN, Eric. (1982) [1952], A Nova Ciência da Política [trad. de José Viegas Filho] (2a ed.). Brasília, Editora UnB.

VOLTAIRE, François-Marie Arouet. (2001) [1762], Comentários Políticos [trad. de Antônio de Pádua Danesi]. São Paulo, Martins Fontes.

WOLFF, Francis. (1999), Aristóteles e a Política [trad. de Thereza Christina Ferreira Stummer e Lygia Araújo Watanabe]. São Paulo, Discurso Editorial. 
Entre o Leviatã e o Beemote: Soberania, Constituição e Excepcionalidade...

WRIGHT, Johnson Kent. (2002), “The Idea of a Republican Constitution in Old Régime France", in M. van Gelderen e Q. Skinner (eds.), Republicanism: A Shared European Heritage. Volume 1: Republicanism and Constitutionalism in Early Modern Europe. New York, Cambridge University Press.

ZARKA, Yves Charles. (2003), “Raison d'État”, in P. Raynaud e S. Rials (eds.), Dictionnaire de Philosophie Politique. Paris, PUF. 


\title{
Christian Edward Cyril Lynch
}

\author{
ABSTRACT \\ Between the Leviathan and the Behemoth: Sovereignty, Constitution, and \\ Exceptionality in $17^{\text {th }}$ and $18^{\text {th }}$ Centuries Political Debate
}

The article seeks to retrace the theoretical approaches to the problem of exceptionality of power, i.e., the manifestation of sovereign power within a limited government with shared power - as in the tradition of mixed Constitution (longstanding in political thinking) - in the $17^{\text {th }}$ and $18^{\text {th }}$ centuries. Already present in authors like Machiavelli, Harrington, and Locke, the debate bifurcated between England and France in the early $18^{\text {th }}$ century. The specificities of English politics led it to consecrate a tradition of mixed Constitutionalism in which the discretionary element lost relevance in the political system as a whole. In France, on the other hand, the unpopularity of the nobility and the centrality of sovereignty as a concept disaccredited formulas that compromised with the discretionary nature of power. This bifurcation contributed to the formation of two distinct patterns of Constitutional government: the Anglo-Saxon and the French/Continental.

Key words: state; sovereignty; Constitution; state of exception

\section{RÉSUMÉ}

Entre le Léviathan et le Behemoth: Souveraineté, Constitution et Exceptionnalité dans le Débat Public aux XVII et XVIII Siècles

Dans cet article, le propos est de montrer les voies théoriques empruntées par la question de l'exceptionnalité du pouvoir, c'est-à-dire la manifestation du pouvoir souverain à l'intérieur d'un gouvernement limité et au pouvoir partagé - cas de la constitution mixte, vieille tradition de la pensée politique européenne aux $\mathrm{XVII}^{\mathrm{e}}-\mathrm{XVIII}{ }^{\mathrm{e}}$ siècles. Débat qu'on retrouve déjà chez des auteurs tels que Machiavel, Harrington et Locke, et qui se dédouble au début du XVIII ${ }^{\mathrm{e}}$ siècle entre l'Angleterre et la France. D'un côté, si les spécificités de la politique anglaise l'ont amenée à consacrer une tradition de constitution mixte où l'élément discrétionnaire voyait son importance amoindrie au sein du système politique, de l'autre, en France, l'impopularité de la noblesse et la centralité du concept de souveraineté ont discrédité les formules s'accommodant du caractère discrétionnaire du pouvoir. Cette bifurcation aurait favorisé la formation de deux modèles différents de gouvernement constitutionnel: l'anglo-saxon et le franco-occidental.

Mots-clé: état; souveraineté; constitution; état d'exception 